\title{
Rosa damascena Flower Oil
}

National Cancer Institute

\section{Source}

National Cancer Institute. Rosa damascena Flower Oil. NCI Thesaurus. Code C107357.

The oil extracted from the flowers of Rosa damascena. Rose oil is used as a frangrance component. 